\title{
Analisis pengaruh sektor pertanian dan sektor perdagangan terhadap produk domestik regional bruto Kabupaten Magelang
}

\author{
Agesti Duwi Wahyuningtias ${ }^{1}$ \\ ${ }^{1}$ Fakultas Ekonomi, Universitas Tidar Magelang \\ ${ }^{*}$ Korespondensi (e-mail: agestidwi24@gmail.com)
}

\begin{abstract}
Gross regional domestic product as a measuring tool for the success of economic development has a significant influence in planning to increase the potential income. Magelang regency is one of them, which has a sector of agriculture and trade that has not been optimized, including the direction of economic policies that are often inconsistent. This study aims to determine the effect of the agricultural sector and the trade sector on the gross regional domestic product of the Magelang Regency. This research is quantitative type research with multiple linear regression analysis methods. Using secondary data published by BPS Magelang Regency 2010-2017. Based on the research results, it is found that simultaneously the agricultural sector and the trade sector influence GRDP, while partially that affects, namely the trade sector, while the agricultural sector has no.
\end{abstract}

Keywords: Agriculture Sector, Trade Sector, Reg ional Domestic Products Gross

\section{Abstrak}

Produk domestik regional bruto sebagai alat ukur keberhasilan pembangunan perekonomian mempunyai pengaruh besar dalam perencanaan peningkatan potensi pendapatan suatu daerah. Kabupaten Magelang salah satunya, yang mempunyai sektor pertanian dan perdagangan yang belum teroptimalkan, termasuk juga arah kebijakan perekonomian yang sering tidak konsisten. Tujuan dari penelitian ini yaitu mengetahui pengaruh sektor pertanian dan sektor perdagangan terhadap produk domestik regional bruto Kabupaten Magelang. Penelitian ini adalah penelitian jenis kuantitatif dengan metode analisi regresi linier berganda. Menggunakan data sekunder yang diterbitkan oleh BPS Kabupaten Magelang tahun 2010-2017. Berdasarkan hasil penelitian diperoleh bahwa secara simultan sektor pertanian dan sektor perdagangan memiliki pengaruh terhadap PDRB, adapun secara parsial yang berpengaruh yaitu sektor perdagan, sementara sektor pertanian tidak berpengaruh.

Kata kunci: Sektor Pertanian, Sekor Perdagangan, Produk Domestik Regional Bruto

How to cite: Wahyuningtias, A. D. (2021). Analisis pengaruh sektor pertanian dan sektor perdagangan terhadap produk domestik regional bruto Kabupaten Magelang. Journal of Economics Research and Policy Studies, 1(1), 1-11.

\section{Pendahuluan}

Pertumbuhan ekonomi merupakan salah satu tolak ukur perekonomian di suatu daerah/wilayah. Pertumbuhan ekonomi merupakan permasalahan jangka panjang yang dihadapi oleh suatu Negara atau wilayah dalam upaya meningkatkan pendapatan nasional rill. Pertumbuhan ekonomi mengukur seberapa besar keberhasilan suatu Negara dalam memproduksi suatu barang atau jasa yang dipengaruhi oleh beberapa faktor yang dapat meningkatkan kesejahteraan 
masyarakat. Salah satu untuk mengukur pertumbuhan ekonomi yaitu dengan melihat jumlah nilai Produk Domestik Bruto (PDB) jika itu dalam lingkup negara dan Produk Domestik Bruto Daerah (PDRB) jika mencangkup suatu daerah Kabupaten/Kota.

Produk Domestik Bruto (PDB) merupakan nilai suatu keseluruhan semua barang dan jasa yang diproduksi di dalam wilayah tersebut dalam jangka waktu tertentu (biasanya per tahun). PDB berbeda dari Produk Nasional Bruto karena memasukan pendapatan faktor produksi dari luar negeri yang bekerja di Negara tersebut. Sedangkan Produk Domestik Regional Bruto (PDRB) merupakan data statistik yang merangkum perolehan nilai tambah dari seluruh kegiatan ekonomi di suatu wilayah pada satu periode tertentu. PDRB dihitung dalam dua cara yaitu atas dasar harga konstan dan harga berlaku (Kapahang etal., 2016)

Jhingan (2012) menyatakan proses pertumbuhan ekonomi dipengaruhi oleh dua macam faktor, yaitu faktor ekonomi dan non ekonomi. Faktor ekonomi seperti sumber alam, sumber daya manusia, modal, usaha, teknologi, dan sebagainya. Faktor non ekonomi seperti lembaga sosial, kondisi politik, dan nilai-nilai moral. Sedangkan Samuelson dan Nordhaus (2009) menyatakan faktor-faktor yang mempengaruhi kegiatan ekonomi dapat dikelompokkan menjadi 2 yaitu faktor internal dan ekstemal. Faktor internal meliputi kebijakan fiskal, kebijakan moneter, kebijakan pendapatan, kebijakan perdagangan. Faktor eksternal meliputi output luar negeri, perang, iklim dan cuaca. Kedua faktor saling berinteraksi yang pada gilirannya mempengaruhi keseimbangan penawaran agregat dan permintaan agregat yang selanjutnya akan mempengaruhi penampilan ekonomi seperti GDP, kesempatan kerja, inflasi dan ekspor netto (Agustono, 2013)

Mellor dan Johnson dalam Tambunan (2010) menyatakan bahwa kegiatan pertanian dan non pertanian berinteraksi secara komplementer dalam suatu pertumbuhan ekonomi. Dengan demikian pertumbuhan ekonomi dapat diukur dengan menggunakan PDRB pertanian dan non pertanian di suatu daerah. Pertumbuhan ekonomi suatu daerah dapat dilihat dengan melihat jumlah PDRB. Pertanian merupakan sektor utama perekonomian di Negara yang sedang berkembang seperti di Negara Indonesia. Sektor Pertanian memiliki peran penting dan strategis dan umumnya signifikan dalam meningkatkan pertumbuhan ekonomi di suatu Negara ataupun daerah. Pertanian sendiri merupakan penyumbang PDB yang cukup tinggi di Indonesia. Selain pertanian perdagangan juga merupakan penyumbang PDB yang cukup untuk Indonesia.

Di Kabupaten yang berada di wilayah Indonesia yang mayoritas penduduknya adalah sebagai seorang petani dan pedagang. Salah satunya yaitu di Kabupaten Magelang. Penduduk di Kabupaten Magelang memang sebagian besar bemata pencaharian sebagai petani. Dapat dibuktikan dengan jumlah PDRB pertanian dan perdagangan yang dimiliki oleh Kabupaten Magelang. 
Tabel 1. PDRB Kabupaten Magelang Harga Konstan 2010

\begin{tabular}{ccc}
\hline Tahun & Pertanian & Perdagangan \\
\hline 2010 & 3618799,33 & 2204607,24 \\
2011 & 3884447,22 & 2335347,69 \\
2012 & 3827627,05 & 2400862,00 \\
2013 & 3900103,18 & 2500051,09 \\
2014 & 3968480,17 & 2588142,41 \\
2015 & 4109141,45 & 2691442,36 \\
2016 & 4245740,24 & 2839003,46 \\
2017 & 4352892,84 & 3020269,63 \\
\hline
\end{tabular}

Di lihat dari Tabel 1, pertanian di Kabupaten Magelang mempunyai jumlah PDRB yang cenderung terus meningkat kurun waktu 7 tahun terakhir dari tahun 2010-2017 hal ini menunjukan bahwa sektor pertanian merupakan sektor yang banyak di geluti oleh masyarakat di Kabupaten Magelang dan merupakan penyumbang PDRB Kabupaten yang paling banyak. Jika dibandingkan dengan sektor pertanian, sektor perdagangan memang mempunyai jumlah PDRB lebih rendah akan tetapi sektor perdagangan juga merupakan penyumbang PDRB tertinggi kedua di Kabupaten Magelang setelah sektor pertanian. Dapat dilihat bahwa sektor perdagangan menyumbang jumlah PDRB yang terus naik dari tahun ke tahun dalam PDRB Kabupaten Magelang. Berdasarkan penelitian ini, maka tujuan penelitian ini yaitu untuk melihat pengaruh sektor pertanian dan sektor perdagangan terhadap produk domestik regional bruto Kabupaten Magelang

\section{Tinjauan Pustaka}

\section{Sektor Pertanian}

Pengertian Pertanian Secara umum adalah suatu kegiatan manusia yang temasuk didalamnya yaitu bercocok tanam, peternakan, perikanan dan juga kehutanan. Sebagian besar kurang lebih dari 50 persen mata pencaharian masyarakat di Indonesia adalah sebagai petani, sehingga sektor pertanian sangat penting untuk dikem bangkan di negara kita.

Pengertian pertanian dalam arti sempit hanya mencakup pertanian sebagai budidaya penghasil tanaman pangan padahal kalau kita tinjau lebih jauh kegiatan pertanian dapat menghasilkan tanaman maupun hewan ternak demi pemenuhan kebutuhan hidup manusia. Sedangkan pengertian pertanian yang dalam arti luas tidak hanya mencakup pembudidayaan tanaman saja melainkan membudidayakan serta mengelola dibidang perternakan seperti merawat dan membudidayakan hewan ternak yang bemanfaat bagi pemenuhan kebutuhan masyarakat banyak seperti: ayam, bebek, angsa. Serta pemanfaatan hewan yang dapat membantu tugas para petani kegiatan ini merupakan suatu cakupan dalam bidang pertanian (Bukhori, 2014). 
Pertanian merupakan sektor ekonomi yang utama di Negara-Negara Berkembang. Peran atau kontribusi sektor pertanian dalam pembangunan ekonomi suatu negara menduduki posisi yang penting sekali. Hal ini antara lain disebabkan beberapa faktor (Mardikanto, 2007). Pertama, sektor pertanian merupakan sumber persediaan bahan makanan dan bahan mentah yang dibutuhkan oleh suatu Negara. Kedua tekanantekanan demografis yang besar di negara-negara berkembang yang disertai dengan meningkatnya pendapatan dari sebagian penduduk menyebabkan kebutuhan tersebut terus meningkat. Ketiga, sektor pertanian harus dapat menyediakan faktorfaktor yang dibutuhkan untuk ekspansi sektor-sektor lain terutama sektor industri. Faktor-faktor ini biasanya berwujud modal, tenaga kerja, dan bahan mentah. Keempat, sektor pertanian merupakan sektor basis dari hubungan-hubungan pasar yang penting berdampak pada proses pembangunan Sektor ini dapat pula menciptakan keterkaitan kedepan dan keterkaitan kebelakang yang bila disertai dengan kondisi-kondisi yang tepat dapat memberi sumbangan yang besar untuk pembangunan. Kelima, sektor ini merupakan sumber pemasukan yang diperlukan untuk pembangunan dan sumber pekerjaan dan pendapatan dari sebagian besar penduduk negara-negara berkembang yang hidup di pedesaan (Pratomo, 2010). Pertanian merupakan salah satu sektor basis yang dikembangkan di Indonesia, berdasarkan penelitian yang dilakukan oleh (Maisaroh, 2017) yang menyatakan bahwa sekor pertanian merupakan sektor basis yang mampu memghasilkan barang dan jasa untuk kebutuhan konsum si local maupun melakukan ekspor ke luar wilayah kabupaten dan atau luar negeri. Peranan sektor pertanian sebagai sektor basis dalam perekonomian menjadi salah satu alasan yang kuat mengapa sektor pertanian menjadi faktor yang selalu menjadi fokus pembangunan perekonomian di seluruh wilayah Indonesia melalui beberapa upaya untuk mendukung kemajuan sektor tersebut (Ningtyas, 2013)

\section{Sektor Perdagangan}

Perdagangan adalah usaha yang bemanfaat untuk distribusikan dari produsen ke konumen. Baik dstribusi dari barang kota ke desa maupun sebaliknya. Kegiatan perdagangan dapat dilakukan dipasar, keliling, swalayan atau membuka toko. Sektor perdagangan merupakan suatu kegiatan ekonomi yang bergerak dalam oenyediaan dan pendistribusian barang yang dibutuhkan oleh mayarakat dan industry melalui mekanisme pasar atau operasi khusus barang-barang kebutuhan masyarakat, baik dalam lingkup domestik ataupun antar Negara (perdagangan internasional) (Aulia, 2020).

Sektor perdagangan dibagi menjadi beberapa sub sektor perdagangan yang mencakup kegiatan menjual dan membeli barang, baik berupa barang baru maupun barang bekas yang mempunyai tujuan sebagai penyaluran atau pendistribusian tanpa merubah bentuk barang tersebut. Sub sektor perdagangan dibagi menjadi 2:

1. Perdagangan besar

Sub sektor ini mencakup kegiatan pembelian dan penjualan kembali barang baru atau barang bekas oleh pedagang dari produsen atau importer ke pedagang besar yang lainya. 


\section{Perdagangan eceran}

Merupakan sub sektor dari pergadangan yang umumnya melayani konsumen perorangan atau rumah tangga dengan menjula kembali barang baru ataupun barang bekas tanpa merubah bentuk.

\section{Produk Domestik Regional Bruto}

Produk Domestik Regional Bruto (PDRB) merupakan nilai tambah bruto seluruh barang dan jasa yang tercipta atau dihasilkan di wilayah domestik suatu negara yang timbul akibat berbagai aktivitas ekonomi dalam suatu periode tertentu tanpa memperhatikan apakah faktor produksi yang dimiliki oleh masyarakat dari daerah itu sendir (residen) ataupun masyarakat lain (non-residen) (Badan Pusat Statistik, 2018) PDRB atas dasar harga konstan dipakai untuk dapat mengetahui pertumbuhan ekonomi dari tahun ke tahun atau dengan kata lain pertumbuhan ekonomi setiap tahunnya (Sukirno, 2006). Sedangkan menurut Badan Pusat Statistik (2018) PDRB atas dasar harga berlaku menunjukkan nilai tambah barang dan jasa yang dihitung menggunakan harga yang berlaku setiap tahun, sedangkan PDRB atas dasar harga konstan menggambarkan nilai tambah barang dan jasa yang dihitung dengan harga yang berlaku pada satu tahun tertentu sebagai dasamya. PDRB atas dasar harga berlaku dapat diperuntukkan sebagai gambaran untuk melihat pergeseran dan struktur ekonomi, sedangkan PDRB atas dasar harga konstan diperuntukkan melihat pertumbuhan ekonomi dari tahun ke tahun. Terdapat 3 pendekatan dalam perhitungan PDRB yaitu, pendekatan produksi, pendekatan pengeluaran dan pendekatan pendapatan. Dalam penelitian ini penulis menggunakan pendekatan produksi dimana dengan melihat unit-unit produksi yang dikelompokkan dalam 17 lapangan usaha/ sektor.Menjelaskan teori, temuan, dan materi penelitian lainnya yang diperoleh dari bahan referensi untuk digunakan sebagai dasar kegiatan penelitian untuk merumuskan kerangka pikiran yang jelas dari perumusan masalah yang akan dipelajari.

\section{Kerangka Berfikir dan Hipotesis Penelitian}

Kerangka berpikir penelitian menupakan diagram yang menjelaskan secara garis besar alur dalam penelitian. Kerangka berpikir penelitian dalam penelitian ini adalah sebagai berikut:

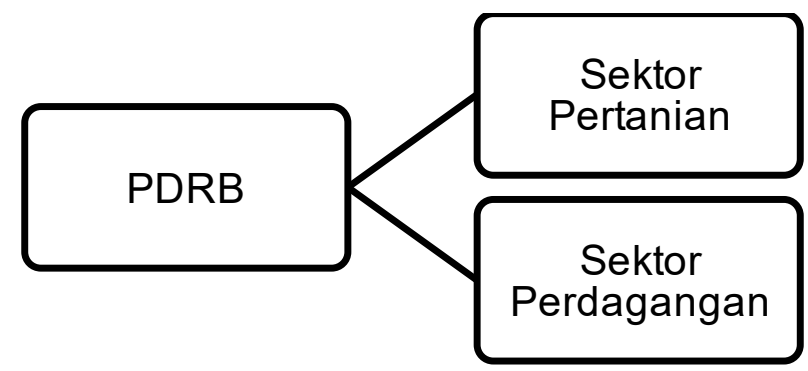

Gambar 1. Kerangka Penelitian

$\mathrm{H}_{1}$ : ada pengaruh positif dan signifikan antara sektor pertanian terhadap PDRB Kabupaten Magelang tahun 2010-2017.

$\mathrm{H}_{2}$ : ada pengaruh positif dan signifikan antara sektor perdagangan terhadap PDRB Kabupaten Magelang tahun 2010-2017. 


\section{Metode Penelitian}

Data dalam penelitian ini menggunakan data sekunder yang bersumber dari BPS Kabupaten Magelang dan BPS Indonesia. Dengan menggunakan pendekatan secara kuantitatif, metode pendekatan kuantitaif adalah metode yang penyajian datanya dengan menggunakan bentuk angka dan analisis data yang bersifat statistik dengan tujuan untuk menguji hipotesis. Dilihat dari sifatnya penelitian ini bersifat deskripsi analisis, karena dalam penelitian ini penulis memberikan gambaran mengenai pengaruh sektor pertanian dan sektor perdagangan terhadap produk domestik regional bruto yang dilihat dari jum lah PDRB di Kabupaten Magelang tahun 2010-2017. Adapun data yang dianalisis yaitu PDRB Kabupaten Magelang tahun 2010-2017 dengan menggunakan ADHK 2010 ,PDRB Sektor Pertanian dengan menggunakan ADHK 2010 dan PDRB Sektor Perdagangan dengan menggunakan ADHK 2010.

\section{Definisi Operasional}

1. PDRB diambil berdasarkan PDRB perkapita atas dasar harga konstan yang menunjukan nilai tambah barang dan jasa yang dihitung dengan menggunakan harga barang konstan pada satuan tertentu sebagai tahun dasar. Dalam penelitian ini menggunakan PDRB atas dasar harga konstan tahun 2010 dalam juta rupiah.

2. PTN (Sektor Pertanian) merupakan jumlah PDRB dalam sektor pertanian yang disumbangkan dalam PDRB Kabupaten Magelang, dengan menggunakan PDRB sektor pertanian atas dasar harga konstan tahun 2010.

3. PDG (Sektor Perdagangan) merupakan jumlah PDRB sektor perdagangan yang disumbangkan dalam PDRB Kabupaten Magelang dengan menggunakan PDRB sektor perdagangan atas dasar harga konstan tahun 2010.

\section{Teknik Analisis Data}

Alat uji analisis dengan menggunakan analisis regresi berganda (OLS), yaitu analisisi bentuk dan tingkat hubungan antara variabel terikat dan lebih dari satu variabel bebas (Widarjono, 2013). Data akan diuji dengan asumsi klasik dan uji hipotesis agar data mempunyai hasil yang jelas dan em piris. Persamaan variabel sebagai berikut:

Keterangan:

$$
P D R B_{\mathrm{t}}=\beta_{0}+\beta_{1} P T N_{1}+\beta_{2} P D G_{2}+\mathrm{e}_{\mathrm{t}}
$$

$\begin{array}{ll}\text { PDRB } & \text { : Produk Domestik Regional Bruto } \\ \beta_{0} & : \text { konstanta } \\ \beta_{1 \ldots .2} & : \text { koefisien PTN, PDG } \\ \mathrm{t} & : \text { tahun } \\ \text { PTN } & : \text { sektor pertanian } \\ \text { PDG } & \text { : sektor perdagangan } \\ \text { e } & \text { : error term }\end{array}$

Dalam penelitian ini akan menggunakan uji asumsi klasik yang akan dilakukan yaitu: uji nomalitas, uji autokorelasi, uji multikolinearitas, dan uji heteroskedastisitas. Kemudian untuk menguji hipotesis maka uji t dan R2 diperlukan dalam penelitian ini. Apabila $t_{\text {hitung }}>t_{\text {tabel }}$ naka hipotesis diterima berarti terdapat pengaruh antara variabel 
independen terhadap variabel dependen dan sebaliknya. Sedangkan Adj.R2 adalah kemampuan setiap variabel independen dalam menjelaskan keragaman variabel dependen.

\section{Hasil dan Pembahasan}

\subsection{Hasil penelitian}

\section{Uji asumsiklasik}

Uji nomalitas merupakan uji yang dilakukan untuk menilai sebaran data dalam suatu keom pok ataupun variabel. Uji nomalitas dilakukan uji Jarque-Bera (Widarjono, 2013)

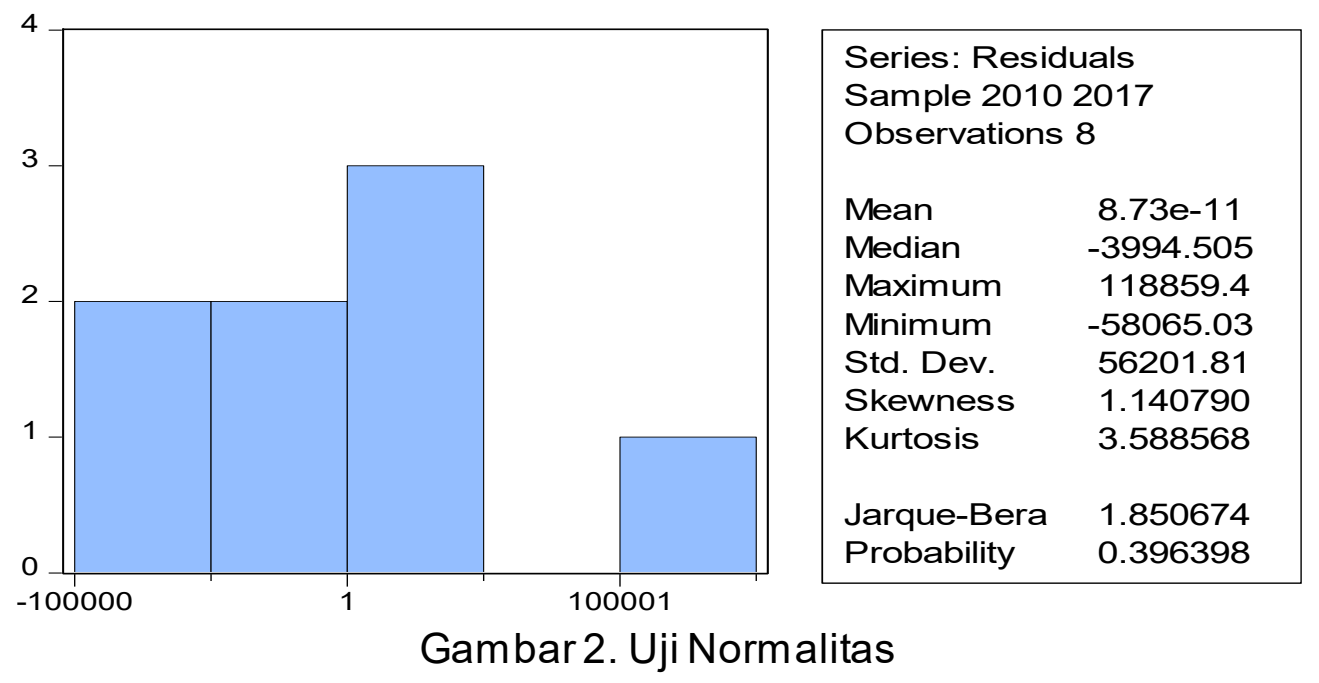

Uji multikolinearitas bertujuan untuk menguji apakah dalam model regresi terdapat korelasi antar variabel bebas atau tidak. Dalam model yang bagus seharusnya tidak terjadi korelasi antara variabel bebas.

Tabel 2. Uji Multikolinearitas

\begin{tabular}{cccc}
\hline Variable & $\begin{array}{c}\text { Coefficient } \\
\text { Variance }\end{array}$ & $\begin{array}{c}\text { Uncentered } \\
\text { VIF }\end{array}$ & $\begin{array}{c}\text { Centered } \\
\text { VIF }\end{array}$ \\
\hline PTN & 0,00491 & 54,36107 & 1,253861 \\
PDG & 0,000156 & 87,93101 & 1,253861 \\
C & $4,41 \mathrm{E}+10$ & 79,7278 & NA \\
\hline
\end{tabular}

Berdasarkan hasil uji multikolineritas Tabel 2 menunjukan bahwa nilai Centered VIF baik sektor pertanian maupun perdagangan adalah 1.253861 dimana nilai tersebut kurang dari 1- maka dapar dinyatakan bahwa model tidak terdapat masalag multikolinearitas.

Tabel 3. Uji Autokorelasi

\begin{tabular}{llll}
\hline F-statistic & 0,300385 & Prob. F(2,3) & 0,7605 \\
Obs*R-squared & 1,334758 & Prob. Chi-Square(2) & 0,5131 \\
\hline
\end{tabular}

Berdasarkan hasil uji autokorelasi Tabel 3 dapat diketahui nahwa nilai Prob. Chi Square(2) yang merupakan nilai $\mathrm{p}$ value uji Breusch-Godfrey Serial orrelation Lm 
yaitu sebesar 0.5131 dimana $>0,05$ sehingga Ho di terima dan Ha Ditolak yang artinya tidak ada masalah autokorelasi serial.

Tabel 4. Uji Heteroskedastisitas

\begin{tabular}{llll}
\hline \multicolumn{4}{l}{ Heteroskedasticity Test: Breusch-Pagan-Godfrey } \\
\hline F-statistic & 0,89466 & Prob. F(2,5) & 0,4654 \\
Obs*R-squared & 2,108393 & Prob. Chi-Square(2) & 0,3485 \\
Scaled explained SS & 1,065961 & Prob. Chi-Square(2) & 0,5869 \\
\hline
\end{tabular}

Berdasarkan hasil dari uji heteroskedastisitas Tabel 4 dapat diketahui bahwa nilai prob. Chi-square(2) sebesar $0.3485>0.05$, maka dapat disimpulkan bahwa tidak terdapat masalah heteroskedastisitas dalam model prediksi.

\section{Pengujian Hipotesis}

Tabel 5. Hasil Persamaan Regresi

\begin{tabular}{crrrr}
\hline \multicolumn{1}{c}{ Variable } & Coefficient & Std. Error & t-Statistic & Prob. \\
\hline PTN & 0,014885 & 0,070074 & 0,212424 & 0,8402 \\
PDG & 0,098419 & 0,012483 & 7,884251 & 0,0005 \\
C & 2222742 & 209929,9 & 10,58802 & 0,0001 \\
\hline R-squared & 0,941099 & & & \\
Adjusted R-squared & 0,917539 & & & \\
F-statistic & 39,94408 & & & \\
Prob(F-statistic) & 0,000842 & & & \\
\hline
\end{tabular}

Nilai R-square sebesar $0.941099(94,1 \%)$ hal ini menunjukan besarnya kemampuan variable bebas adalah sebesar $94,1 \%$, sehingga dapat diartikan bahwa sektor pertanian dan sektor perdagangan berpengaruh sebesar $94,1 \%$ terhadap Produk Domestik Regional Bruto (PDRB), sisanya sebesar 5,9 \% (100\% - 94,1\%) dijelaskan oleh variabel lain yang tidak diteliti atau tidak dimasukkan dalam model. Sementara nilai probabititas $\mathrm{F}$ statistik sebesar 0.000010 artinya nilai probabititas $\mathrm{F}$ statistik lebih kecil dari $a=0,05(0.000010<0,05)$ maka Ho ditolak.

Variabel Sektor Pertanian memperoleh nilai koefisien sebesar 0,014885 , nilai tstatistik sebesar 0,212424 dan nilai probabilitas Sebesar 0,8402( $>5 \%)$ maka variabel Sektor Pertanian berpengaruh negatif dan tidak signifikan terhadap PDRB. Variabel PDG (Sektor t-statistik sebesar 7,884251 dan nilai prob.0,0005(<5\%) maka variabel PDG (Sektor Perdagangan) berpengaruh signifikan terhadap PDRB. Adapun model regresinya, maka dapat dilihat pada estimation berikut:

$$
\begin{array}{ll}
\text { Estimation Command } & \text { :LS Y C X1 X2 } \\
\text { Estimation Equation } & : Y=C(1)+C(2)^{*} P T N+C(3)^{*} P D G \\
\text { Substituted Coefficients } & : Y=2222742+0,014885^{*} P T N+0,098419 * \text { PDG }
\end{array}
$$

\subsection{Pembahasan}

\section{Sektor pertanian dan produk domestik regional bruto}

Secara teori sektor pertanian dan sektor perdagangan merupakan salah satu faktor yang mempengaruhi adanya peningkatan PDRB di suatu wilayah tertentu. Dalam penelitian PTN (Sektor Pertanian) tidak memiliki pengaruh yang signifikan dalam Uji t terhadap Produk Domestik Regional Bruto. Penelitian ini tidak sejalan dengan 
pendapat dari Mellor dan Johnson dalam Tambunan (2010) bahwa kegiatan pertanian berinteraksi secara komplementer dalam suatu pertumbuhan ekonomi. Secara empiris penelitian ini tidak sejalan juga dengan pendapat dari Riyanto (2015) yang dalam penelitiannya berpendapat bahwa sektor pertanian mempunyai pengaruh temadap besamya produk domestik regional bruto suatu wilayah. Pendapat yang tidak sejalan juga didapat dari Ghofir \& Soesatyo (2014) yang berpendapat bahwa sektor pertanian memiliki pengaruh yang signifikan terhadap PDRB. Peranan nyata dari sektor pertanian yang memberikan pengaruh terhadap produk domestik regional bruto, pendapat tersebut diutarakan oleh Margunani (2002) dalam penelitian yang dilakukan.

Secara Empiris penelitian ini sejalan dengan pendapat dari Pradnyana (2012) yang menyatakan bahwa sektor pertanian tidak dominan pengaruhnya terhadap produk domestik regional bruto. Hidayat (2011) berpendapat juga bahwa sektor pertanian tidak memiliki pengaruh yang signifikan terhadap produk domestik regional bruto. Indikasi adanya hasil yang tidak signifikan dapat dikarenakan bahwa dalam sektor-sektor yang ada dalam perekonomian suatu wilayah telah semakin seimbang dengan adanya alih fungsi lahan yang semakin pesat untuk memenuhi kebutuhan perumahan ataupun lainya bagi warga Kabupaten Magelang, sehingga untuk mengatasi hal tersebut perlu dicarikan solusi terutama untuk masalah-masalah utama yang menyebabkan kondisi tersebut seperti alih lahan pertanian tanah yang sangat pesat dan lain sebagainya, sehingga menurunya sektor pertanian dapat ditanggulangi.

\section{Sektor perdagangan dan produk domestik regional bruto}

PDG (sektor Perdagangan) memiliki pengaruh yang positif dan juga signifikan terhadap Produk Domestik Regional Bruto Kabupaten Magelang, dimana hal tersebut berarti setiap kenaikan pada PDRB sektor perdagangan berdampak pada PDRB Kabupaten Magelang. Penelitian ini tidak sejalan dengan pendapat Ovilia (2018) yang dalam penelitiannya berpendapat bahwa sektor perdagangan tidak memiliki pengaruh terhadap PDRB, hal tersebut disebabkan oleh beberapa faktor diantaranya karena sektor perdagangan lebih berpartisipasi terhadap pengurangan pengangguran dan kesejahteraan masyarakat, sehingga hanya cukup dalam meningkatkan pendapatan individu atau rumah tangga saja, dan kurang memiliki pengaruh terhadap pendapatan daerah.

Secara empiris penelitian ini sejalan dengan pendapat dari Dwi Prio (2008) yang berpendapat bahwa pertumbuhan ekonomi pada sektor perdagangan mempunyai pengaruh positif terhadap PDRB, Riyanto (2015) berpendapat juga bahwa sektor perdagangan merupakan sektor yang memiliki kontribusi yang besar penyumbang produk domestik regional bruto di suatu wilayah. Yulianto et al ( 2015) berpendapat juga bahwa sektor perdagangan merupakan sektor yang mempunyai pengaruh yang bersar dalam mendorong perubahan total output pertumbuhan di suatu wilayah. Penelitan ini juga sejalan dengan pendapat dari Pradnyana (2012) bahwa sektor perdagangan mempunyai pengaruh positif secara parsial. 
Secara simultan sektor pertanian dan perdagangan memiliki pengaruh yang signifikan terhadap PDRB Kabupaten Magelang. Penelitian ini sejalan dengan studi empiris dari Ovilia ( 2018) dan Hidayat (2011) yang berpendapat bahwa secara bersama-sama atau secara simultan adanya pengaruh yang signifikan antara sektor pertanian dan sektor perdagangan terhadap laju pertumbuhan PDRB. Analisis sektor pertanian dan sektor perdagangan yang menjadi pengaruh terhadap produk domestik bruto diantaranya karena sektor pertanian merupakan penghasil pangan, bahan baku industri, pembangunan daerah pedesaan dan juga sebagai kesempatan kerja bagi masyarakat agar dapat menekan tingginya tingkat pengangguran, dari sisi perdagangan pengaruhnya terjadi karena adanya kegiatan-kegiatan perdagangan yang dapat meningkatkan dan ikut menyokong pendapatan daerah.

\section{Kesimpulan}

Berdasarkan dari hasil analisi data dan pembahasan yang dilakukan peneliyi dapat ditarik kesimpulan bahwa dari hasil uji signifikansi sektor perdagangan berpengaruh secara positif terhadap Produk Domestik Regional Bruto. Sem entara sektor pertanian tidak berpengaruh terhadap Produk Domestik Regional Bruto. Berdasarkan hasil uji signifikansi simultan menunjukkan Sektor pertanian dan sektor perdagangan secara simultan berpengaruh signifikan terhadap Produk Domestik Regional Bruto (PDRB).

\section{Ucapan Terimakasih}

Peneliti mengucapkan banyak terimakasih kepada civitas akademika Universitas Tidar Magelang yang telah membantu dan mendorong penyelesaian penelitian ini.

\section{Referensi}

Agustono. (2013). Analisis Sektor Pertanian Ditinjau Dari Peran Terhadap Pertumbuhan Dan Stabilitas Produk Domestik Regional Bruto Di Provinsi Jawa Tengah. Sepa, 9(2), 283-296.

Aulia, R. N. (2020). Pengaruh Sektor Pertanian dan Sektor Perdagangan terhadap Laju Pertumbuhan PDRB di Sumatera Utara Tahun 2011-2019. In Orphanet Journal of Rare Diseases (Vol. 21, Issue 1). Universitas Islam Negeri Sumatera Utara.

Badan Pusat Statistik, B. (2018). Statistik Daerah Kabupaten Magelang. Badan Pusat Statistik Kabupaten Magelang.

Bukhori, M. (2014). Sektor pertanian terhadap pembangunan di Indonesia. Agroteknologi, 1-15.

Dwi Prio, S. (2008). Analisis Pengaruh Sektor Perdagangan Terhadap Pertumbuhan Ekonomi dan Beberapa Faktor Yang Mempengaruhi Sektor Perdagangan Di Kota Medan. Institute Pertanian Bogor.

Ghofir, A. A., \& Soesatyo, Y. (2014). Pengaruh Industri Pengolahan Perdagangan, Hotel, Dan Restoran, Dan Pertanian Terhadap PDRB Kabupaten Mojokerto. Jurnal Pendidikan Ekonomi, 2(3).

Hidayat, W. A. (2011). Analisis Penganuh Sektor Pertanian, Sektor Industri, dan Sektor Perdagangan Terhadap Produk Domestik Regional Bruto (PDRB) 
Kabupaten Pekalongan atas dasar harga berlaku Dengan Program SPSS 16. Universitas Negeri Semarang.

Jhingan, M. . (2012). Ekonomi Pembangunan dan Perencanaan. Raja Grafindo Persada.

Kapahang, R., Koleangan, A. ., \& Wauran, P. C. (2016). Analisis Potensi Perekonomian Kabupaten Minahasa Tenggara. 16(01), 172-184. file:///C:/Users/hp/Downloads/10626-21169-1-SM.pdf

Maisaroh, S. (2017). Analisis Peranan dan Kontribusi Sektor Pertanian terhadap Pertumbuhan Wilayah dalam Prespektif Ekonomi Islam (Studi pada Kabupaten Tulang Bawang). Universitas Islam Negeri (UIN) Raden Intan.

Mardikanto, T. (2007). Pengantar Ilmu Pertanian. Pusat Pengembangan Agrobisnis dan Perhutanan Sosial.

Margunani. (2002). Pengaruh Output Sektor Pertanian Terhadap Produk Domestik Bruto Propinsi Jawa Tengah. Dinamika, 11(2), 57-70.

Ningtyas, B. (2013). Dampak Pembangunan Sektor Pertanian Terhadap Perekonomian Jawa Timur: Studi Kasus Penerapan Model Input Output. https://repository.unej.ac.id/handle/123456789/26180

Ovilia, A. V. (2018). Pengaruh Sektor Pertanian Dan Sektor Perdagangan Terhadap Produk Domestik Regional Bruto (PDRB) Kabupaten Pringsewu Periode 20082016 Dalam Prespektif Ekonomi Islam (Vol. 7). UIN Raden Intan Lampung.

Pradnyana, I. G. G. O. (2012). Pengaruh Sektor Pertanian dan Sektor Perdagangan,Hotel dan Restoran terhadap Produk Domestik Reginal Bruto (PDRB) Kota Denpasar. Angewandte Chemie International Edition, 10(1).

Pratomo, S. (2010). Analisis Peran Sektor Pertanian Sebagai Sektor Unggulan di Kabupaten Boyolali [Universitas Sebelas Maret]. https://core.ac.uk/download/pdf/12348209.pdf

Riyanto, A. (2015). Pengaruh Sketor Pertanian, Industri, dan Perdagangan Terhadap Produk Domestik Regional Bruto (PDRB) Kota Semarang. Jawa Tengah.

Samuelson, P. A., \& Nordhaus, W. D. (2009). Economics nineteenth edition. www.mhhe.com

Sukirno, S. (2006). Ekonomi Pembangunan (A. Supriyatna (ed.); kedua).

Tambunan, T. (2010). Pembangunan Pertanian dan Ketahanan Pangan. Jakarta UIPress.

Widarjono, A. (2013). Ekonometrika (kelima). UPP STIM YKPN.

Yulianto, G. D., Jumiati, A., \& Santoso, E. (2015). Analisis Peranan Sektor Perdagangan Terhadap Perekonomian Wilayah di Kabupaten Jem ber ( Analysis of The Role The Trade Sector Against Economic Areas in Jember Districk ). Universitas Jember. 